\title{
Article
}

\section{Literacy practices, identity and engagement: integrating multifaceted identities of college students to support learning}

Brzeski, Angela

Available at https://clok.uclan.ac.uk/17566/

Brzeski, Angela (2017) Literacy practices, identity and engagement: integrating multifaceted identities of college students to support learning. Research in Post-Compulsory Education, 22 (3). pp. 391-408. ISSN 1359-6748

It is advisable to refer to the publisher's version if you intend to cite from the work. http://dx.doi.org/10.1080/13596748.2017.1358519

For more information about UCLan's research in this area go to http://www.uclan.ac.uk/researchgroups/ and search for <name of research Group>.

For information about Research generally at UCLan please go to http://www.uclan.ac.uk/research/

All outputs in CLoK are protected by Intellectual Property Rights law, including Copyright law. Copyright, IPR and Moral Rights for the works on this site are retained by the individual authors and/or other copyright owners. Terms and conditions for use of this material are defined in the policies page. 


\title{
Literacy practices, identity and engagement: integrating multifaceted identities of college students to support learning
}

\author{
Dr Angela Brzeski
}

Senior Lecturer in Education Studies, University of Central Lancashire, England

UCLan Harrington Building, 11 Victoria Street, Preston PR1 7QS, United Kingdom

Telephone no.: 01772892714

abrzeski@uclan.ac.uk

Dr Angela Brzeski was involved as a practitioner researcher in the Literacies for Learning in Further Education project, a collaboration between two universities - Stirling and Lancaster - and four colleges. Following this, she completed a PhD with a strong focus on classroom and home literacy, engagement and identity. 


\section{Literacy practices, identity and engagement: integrating multifaceted identities of college students to support learning}

This article explores the relationship between the identities and engagement in literacy practices across the home and college domains through case studies of two contrasting students studying on a Childcare course at a Further Education (FE) college in the United Kingdom. The data are drawn from classroom observations, analysis of artefacts and semi structured interviews with the students and their teacher. Findings show that there are specific literacy practices associated with specific identities and that aspects of these are utilized, and engaged with, by students in the college classroom to support their learning. It has also shown that identity is a fundamental part of, and an influencing factor upon, the literacy practice itself. Based on the findings, the suggestion is made for the exploration of the multi-faceted college student identity to become an integral part of FE induction, tutorial, classroom practices and pastoral systems.

Key words: Identity, literacy practices, engagement, Further Education

Word count $-7,339$

\section{Introduction}

My research is drawn from one of the largest Further Education (FE) colleges in England, situated in the city suburbs within the North West of the UK. The college provides courses for a 
diverse student population, from younger students (aged 16 to 18 years) who have recently left high school to mature adults (aged 19 plus) returning to education after time out to work and/or raise families. Whatever the aspirations, needs and commitments of students, the College seems to have something to offer and is proud of its success rates. However, despite the best efforts of the teaching staff, not every student is successful. Other students, on paper, have all the appropriate entry qualifications, but still struggle to complete their course, with some not completing at all.

This study aims to explore the relationship between multifaceted student identities (Ivanic et al. 2009) and engagement in literacy practices across the classroom and home domains. The study enquires into whether there are specific literacy practices associated with specific identities and if these relate to students' engagement in the classroom. Previous studies have uncovered overlaps and connections between the reading and writing that students do in their everyday lives and the literacy demands of their courses, the most notable being the Literacies for Learning in Further Education Project (LfLFE) (Ivanic 2009, Ivanic et al. 2007, 2009). The Project drew on work already carried out on literacy practices engaged in by people in schools, higher education and the community (see, for example, Barton and Hamilton 1998, Barton, Hamilton and Ivanic 2000, Hull and Schultz 2002, Pahl and Rowsell 2005, Smith 2005, Ivanic and Satchwell 2007) and aimed to extend the insights gained from these studies into further education. The project found that identity was an aspect, or micro-practice, of a literacy practice and considered it to be a resource for learning. Other studies have focused on identity and student engagement, for example Wortham (2006), and this article, together with the research associated with it, is a valuable contribution to the knowledge base in this area. The 
examination of the role of identity in student engagement with literacy practices, both at home and in the classroom, sets this study apart from previous studies.

The article starts by providing the conceptual background, commencing with an overview of the social-practices approach to literacy which underpins the study. I follow this with a discussion of the theoretical arguments around literacy, learning and identity, focusing firstly on the definitions and concepts surrounding 'identity' and, secondly, on classroom perspectives. After detailing the methodology, methods and analytical frameworks, I present two contrasting case studies which detail students' experiences of classroom and home literacy practices. Through these case studies, I argue that students' classroom literacy experiences are influenced by the relationship between the literacies in their everyday lives, the literacy practices that these entail and, crucially, their identities. I conclude with recommendations for FE teaching practice and signposts to future research.

\section{Conceptual background}

\section{Literacy, learning and identity - a social-practices approach}

The notion of what constitutes 'literacy' has shifted over time, from the decoding of words, where it is placed in the realm of an individual cognitive skill, to that of literacy as a social practice (Street 1984; Gee 2015; Barton and Hamilton 2000; Barton 2007; Hamilton 2012). In the simplest sense, 'literacy practices are what people do with literacy' (Barton and Hamilton 2000, 7). Literacy practices shape the way we relate to and interact with literacy and are interwoven with our identity and everyday activities. Put simply, reading and writing is a practice that involves people communicating with each other or relating to one another (Fowler 
and Mace 2005; Papen 2005). Social approaches to literacy are sometimes grouped together under the remit of the New Literacy Studies (NLS). Within this complex view of the nature of literacy, this study highlights that literacy has many purposes for the learner.

\section{Literacy, learning and identity - definitions and concepts}

According to Gee (2004), the primary identity, or 'sense of self', is molded in the home during childhood. Kershen (1998) positions identity as a complex construct, never static but constantly fluctuating, suggesting that identity is multi-faceted (Ivanic et al. 2009). Identities consist of several different dimensions out of which people appear to seek out their 'most suitable' selves (Woodard 2002). The embryonic nature of identity is illustrated by Dilman (1991), who argues that people change in the course of their lives in ways that the various objects and artefacts in the surroundings of their everyday existence do not. Ivanic et al. (2009) view identity as a person's sense of who they are and who they want to become, chiming with Dilman (1991) who suggests that the 'self' is what a person is searching for when he/she looks inwardly and considers 'who am I?'.

Lewis, Enciso and Moje (2007) perceive identity as a fluid, socially and linguistically mediated construct which accommodates the different positions, or roles, that individuals enact or perform. Identity is an intangible concept arising from, and influenced by, related, more tangible, observable, concrete roles. Identity is how people see themselves, something they identify with whereas roles are what people have to do or need to fulfill.

Identity incorporates identification with and agency by those who identify with a perspective (Woodward 2002, Lewis, Enciso and Moje 2007). Chappell et al. $(2003,32)$ agree 
that sharing an identity with others requires active engagement and awareness, where there is a 'knowing conscious subject' right at the centre of the individual. We choose to identify with a particular person or group. Though structures or forces beyond a person's control shape identities, there is a degree of control which can be exerted (Woodward 2002, 2004), limited by material and social aspects.

Regarding how identities are produced, this occurs through discourse (Foucault 1978). Identities are constructed as language is used at home and in the classroom (Brown 2008). Discourse is more than language; it also encompasses culture and the full range of practices and texts. According to Foucault (1978), discourse includes a range of practices, ways of speaking, writing, interacting and thinking, the full range of how meanings are produced within a culture. In the home, Barton and Hamilton (1998) explain that people assert their identities through literacy practices and demarcate themselves, their partners and other members of their households in terms of literacy practices such as 'I usually read to the children and he buys the newspaper'. Furthermore, Papen (2005) highlights that, as literacy is a social practice, then this commonly implies the cultural, that is, the values, ideas, conventions, worldviews and identities that shape the event of which literacy is a part. Therefore, identity is an integral part of, and an influencing factor upon, the literacy practice itself.

Another perspective relating to identity formation is that it is constructed through relations of difference (Woodward 2002, 2004). People mark themselves as having the same identity as some but different to others. Identity is marked by similarity, the 'people like us' (Gee 2008) and by difference, those who are not like us. Identity formation involves setting boundaries, which locate the parameters of difference and sameness and occurs through the 
language used, how it is spoken, the words and images utilized and the rites and rituals in which a speaker engages.

A further concept is that relationships with peers, adults and family members contribute significantly to identity construction (Brown 2008, Woodward 2002, 2004). This chimes with Chappell et al. (2003) who agree that social relations have a powerful role in identity formation. Similarly, Locke Davidson (1996) views identity as the presentation of the self within a myriad of social relationships, it is a pattern of social assertion that significant others recognize and come to expect. Difference must be accommodated and managed or tensions can arise (Woodward 2002). Furthermore, identity has material bases, mapped out and represented through material items a person chooses to use, wear and their meaning in the wider context. Consumption is a 'fundamental process by which we create identity' (Miller 1997, 17).

'Storying the self' is a strategy used in the search for coherence within the construction of identity (Paris and Winn 2014, Woodward 2002). Stories of the self are purposeful and reflect a person's wish to make sense of who they are through constructing the past by choosing and relating their own stories and constructing meanings.

\section{Literacy, learning and identity - classroom perspectives}

According to Gee (2004), language practices in the home are not principally concerned with skills but with providing the child with values, attitudes, perspectives, motivations and ways of interacting, all of which construct the primary identity that a child picks up through early socialisation. A child becomes 'a person like us' (Gee 2004), a member of a particular family belonging to a specific social group. Luttrell and Parker (2001) add that students use literacy 
practices to form identities within, and sometimes in opposition to, the 'figured', or perceived, worlds of school, work and family. Students' uses of reading and writing are linked to their interests and identities, but school structure does not always acknowledge personal literacies and identities.

Gee (2004) uses the metaphors of play and playing the game to link learning and student identity. To read, a person has to 'play' in the domain so that they can give situation-specific meanings to the associated style of language. The person experiences the situation, via action or talk, to which the words apply. Gee (2004) argues that learning is not just about skills but is 'learning the right moves' to make within interactions to get a person recognized as 'playing the game', enacting the right type of identity for a given situation. In the classroom, deep activity and critical learning is inextricably caught up with identity (Gee 2008). A person cannot learn in a deep, analytical way within the classroom without committing to the learning, which requires that they are willing to see themselves in terms of a new identity, as the kind of person who can learn, use and value the contents of the classroom.

Finally, Smyth and Fasoli (2007) align student identity with the concept of young people having multiple identities. Succeeding at college may mean having to subdue other identities to act within a narrowly defined and institutionalized view of what it means to be a 'good' student, a process known as 'identity formation'. 


\section{The study}

\section{Methodology, methods and analysis}

An ethnographic methodological framework was chosen for the research which investigated the literacy practices of eight further education students across both the home and classroom domains. This methodology was traditionally used by members of the New Literacy Studies (NLS) for researching literacy and social practices (Barton and Hamilton 1998, 2000; Papen 2005) and is particularly suited to the concept of literacy as social practice.

I undertook the role of a participant observer. An independent researcher, I positioned myself as an 'outsider', gathering data via classroom observations, analysis of artefacts and oneto-one semi-structured interviews with class teachers and students. The interviews focused on classroom and home literacy practices, which the students were asked to photograph beforehand (Hodge and Jones 2000). The data was collected during one academic year.

All data were given qualitative codes and the participants' identities were analyzed by 'vertical slicing' followed by 'horizontal slicing' (Barton and Hamilton 1998, 70). Vertical slicing provided a coherent profile of the relationship between home and college literacy practices, identity and engagement in learning for each participant. To look across all participants, horizontal slicing, or 'everything about one concept and how it is realized across a range of people' followed.

Prior to the data collection, I informed the participants of the research purpose and written agreement for their participation was obtained. Participants were told that their contribution to the study was voluntary and were assured that they could withdraw at any time. All of the names reported in this study are pseudonyms. 


\section{Participants and setting}

This study was part of a larger project which had a focus on literacy, identity and student engagement in learning within Further Education. The larger project had eight student participants who were enrolled on courses at the college (see Table 1) and this article will focus on Pauline and Katy, two contrasting case studies. Previous articles have focussed on Russell and Paul (Brzeski 2008) and Luis (Duckworth and Brzeski 2015). Katy and Pauline were chosen for this article as they shared similarities with all of the other participants and the findings presented in this article mirror all of the findings of the larger project.

\section{TABLE 1}

Background information for student participants

\begin{tabular}{lllll}
\hline No. & Pseudonym & Gender & Age range & Course Studied \\
\hline 1 & Pauline & F & 19 plus & Childcare \\
2 & Katy & F & 19 plus & Childcare \\
3 & Russell & M & 19 plus & Construction \\
4 & Paul & M & 19 plus & Construction \\
5 & Matthew & M & $16-18$ & Business Studies \\
6 & Sofia & F & $16-18$ & Business Studies \\
7 & Luis & M & $16-18$ & English \\
8 & Rebecca & F & $16-18$ & English \\
\hline
\end{tabular}

Pauline and Katy were students on the Level 3 Childcare course taught by Linda. The course had a two year duration and Pauline and Katy were both in their first year, attending classes in 
college one day per week and a work placement two days per week. On the work placement, a $\log$ had to be completed which recorded all the activities carried out. In college, Pauline and Katy were assessed by Linda and they were expected to undertake a significant amount of homework and research outside of class. For assessment purposes, Katy and Pauline had to write assignments of up to 2,500 words and these had to be submitted to Linda by a fixed date, which was non-negotiable.

During observations, I noted Pauline and Katy's reactions to a range of literacy practices which had the purpose of developing knowledge and understanding around childcare and, assessing this knowledge and understanding. I observed cross referencing assignments to set criteria, completing gapped handouts by referring to preprinted information, copying down notes from PowerPoint slides, discussion around scenarios printed on a handout, reading handouts aloud to peers and using the Internet for research.

\section{The case studies - two contrasting students}

\section{Case study one: Pauline}

Pauline, in her early 20s, lived at home with her parents and brother. At the age of 16, Pauline came to the college to study Advanced (A)-levels but only completed the first year of the two year course, after which she left to attend another college where she studied Childcare, leaving after a year as she 'got sick of that'. Pauline then worked full time as an administrator for three years, got 'bored of that' and so returned to her first college to restart the same Childcare course. Now a full time student again, Pauline received financial support from her parents and was also 
employed by the private school and nursery where she carried out her unpaid college placement. In the future, Pauline hoped to train as a Primary School teacher.

\section{Pauline's identities}

Pauline had a 'multi-faceted' former, current and aspirational identity. She had been a student on two previous occasions and, before enrolling on her current course, Pauline had worked full time as an administrator. At the time of the study, Pauline was a student but still worked part time and both shaped her identity. She had ambitions to attend university and become a primary school teacher. Pauline was receiving financial backing from her parents and her discussion around this revealed other important dimensions to her identity. I will now present Pauline's identities and literacy practices, across the college and home domains.

\section{Pauline's former identity}

Pauline identified several literacy practices from her administrative posts which now supported her as a student: taking notes from discussions, writing lists and reminders, making diary entries. Referring to note taking in class, Pauline explained 'It's easy ... I've done a lot of ... Before I came to college ... I was in a lot of office jobs ... Minute taking, I got that [skill] from doing that.' Writing lists helped her to be organised 'like if I've got a lot to do, like say homework, I write a big list and tick it off as I do it.'. Writing on Post It notes was helpful 'Like if I know I've got to do things in nursery, I'll put stickers, sticky notes up on places' as was her diary 'Yeah I write everything down, otherwise I will forget. I know if I've written it down that I'm more likely to do it then.' Through her storying, Pauline reconstructed elements of her past to make sense of who she was - an organized college student with a variety of literacy skills (Paris 
and Winn 2014, Woodward 2002). Pauline presented herself as someone who found some college literacy practices straightforward and undemanding. In one of her classes, she made a handwritten note in her diary of when she needed to bring in a childcare-related DVD from home for peers to watch, explaining 'I find it easy being organised doing that, because I'm quite organised.' Pauline found her diary 'easy' to use and presented herself as systematic and orderly through the declarative 'I'm quite organised'. Just as she did as an administrator, Pauline used her diary as a tool for organization purposes. Her identity was symbolised and made visible by her literacy practice of keeping a diary (Gee 2004, Ivanic et al. 2009, Woodward 2002).

\section{Pauline's current identity}

Pauline explained 'My dad's very good when I get stuck! I'm a “daddy's girl”, adding that both parents 'bail her out' financially. Pauline's use of the affectionate term 'daddy's girl' and the verb 'bail' combine to present her as both a daughter and a child who needed to be supported by her parents. Her father had offered to support her through university 'He'll pay for me to go to uni, so that's good ... He'll pay for my fees and stuff.' Pauline's father worked in a local Government job and I suggest that he wanted his daughter to join him in belonging to a wellpaid, highly educated social group. Pauline's desire to go to university appeared to be partly a product of her society and her relationship with her father.

Pauline attended college classes every Wednesday, working as a nursery assistant on a childcare placement on Mondays and Fridays to cover the practical side of her course. In one college class, Pauline's teacher, Linda, used a PowerPoint (PP) presentation, pre-printed handouts and scenarios to teach new theory. Linda asked the entire group to take notes from the 
PP and handouts provided but Pauline stopped after a few minutes. I noted 'Pauline did not appear to be paying much attention. She was not looking at the handout and busied herself with biting her nails'. Linda took Pauline outside of the class to speak to her, returning with Pauline a few minutes later. Later, Linda related their conversation to me. She had noticed that Pauline took 'hardly any notes' and, when questioned, she replied 'well I've done it before'. Linda, frustrated by this response, pointed out that, as she was frequently late in completing homework and had missed some classes, Pauline should record all the hints and tips provided in classes as these would help with assignments. In this situation, Pauline was refusing to comply with the literacy practice of copying down notes as expected by Linda and, consequently, was considered to be not 'playing the game', not enacting the right type of identity expected of her in the classroom, that of a student, made visible by engagement with the literacy practice of notetaking. Linda had associated Pauline's lack of note taking as a sign that she was disinterested and lacking in motivation, culminating in her withdrawal from the class (Gee 2004, Luttrell and Parker 2001).

Pauline's version of the above incident revealed a mismatch between her own preferred classroom literacy practices and those valued by her teacher. Pauline made judgments regarding the value or importance of the information presented to her before noting it, opting not to write down every single word automatically as requested by her tutor. Pauline exercised her agency (Lewis, Enciso and Moje 2007, Woodward 2002) not to disengage with her student identity but to disengage with classroom practices that she did not view as necessary or purposeful to her student identity. This disengagement was reflected by Pauline's continual use of the negative adjective 'boring' when describing classroom practices. She stated 'I prefer getting them [notes from Linda] on a photocopied sheet, reading through it and then high-lighting the bits that are 
important rather than just sitting all day, writing....you see I find it boring writing from PPs ...

find it really boring.' Pauline could then 'put it [the highlighted handout] in [her] file rather than having to copy it down', adding 'if they're [her teachers] talking about something that's important or useful then .... I'll just write like bullet points.' When Pauline was highlighting or note taking, her judgments about what was valuable to highlight or note down were driven by her identity as somebody who was not a passive learner, simply accepting and absorbing all knowledge imparted by the teacher but as an independent, active learner who, based on her prior knowledge, could decide what was relevant to copy or not (Ivanic et al. 2009). Pauline had started the course before and viewed herself as different to her peers. As an administrator, Pauline had learned to extract and record key points and was used to, we can expect, being required to think independently about what was or was not relevant. This was what she now preferred to do in class. Tension arose between Pauline and Linda due to their differences in perspectives - how Pauline saw herself and how Linda saw Pauline did not correlate. In class, Linda perceived Pauline as a recipient of knowledge, associated with note taking which Pauline resented. However, Pauline did not see herself as someone who needed notes as she knew the information (Ivanic et al. 2009, Woodward 2002).

In addition to attending college each week, Pauline carried out unpaid professional practice at a nursery for two days per week, the same setting where she carried out paid work. At this nursery, Pauline had two roles which came together: unpaid student worker and paid employee and these roles did not appear to clash. At the nursery, Pauline was positioned very differently to a college student in the classroom. On placement and in her paid work, Pauline was not expected to receive knowledge but use it and apply it, an approach which seemed to suit her. As a childcare worker, Pauline used literacy practices that allowed her to act as a 
professional - even if in training - that gave her the identity of somebody who had the knowledge already, not as someone who had to learn, as in the classroom. Pauline carried out a range of reading and writing activities for the children in her care: taking the register, creating written plans of activities, filling out accident report forms, writing names on art work, reading stories, updating daily charts for each child, interpreting medical forms and reading the names in shoes and clothing of children. These literacy practices positioned Pauline as a nursery assistant, having responsibility and acting independently based on her experience and knowledge.

As well as being a college student, Pauline was also a part time employee and she identified strongly with being a wage earner. Pauline's working identity had been formed and reinforced through a recent series of jobs and was now so strong that Pauline could not let go of it. Despite being a college student, Pauline was trying to retain the same identity, and associated standard of living, that she had as a full time administrator. She was fully aware of her inability to leave her status as an income earner behind her:

Because I work a lot, it's hard to get balance between work and college, because I know college is important, but at the same time, because I've been used to so much money working full-time then I've dropped to virtually nothing. Because I don't get, even though it looks like a lot of hours, because of my placement, and because of college, it's not a lot really in your hand.

Pauline's tutor, Linda, recognized Pauline's difficulties, explaining she was 'struggling' as she had 'come from employment ... she's given up all that to come back to college. So she's finding the money side of coming back to college a big shock because she's got a car to run and everything.' To earn sufficient money to maintain her previous lifestyle, Pauline devoted a 
disproportionate amount of her time each week to her paid work compared to the time she apportioned to her college course. This resulted in a dissonance created by conflict between Pauline's identity as a paid employee and that of a classroom based college student:

I go to work on the Monday, it is half seven until six, but from like nine until four I'll do my placement. And other times there's before school care and after school care. Tuesdays it's before school care and nursery and after school care. Wednesday it's before school care, college then nursery, then after school care, Thursday's the same. Friday it's before school care, nursery and then after school care.

Pauline seemed determined to retain the luxuries of a salary earner. Her identity had material bases, mapped out and represented through the material items she chose to purchase, for example she was saving for a Caribbean holiday and running a car (Miller 1997). What Pauline bought and consumed contributed to her sense of who she was - an independent young woman with an attractive lifestyle. By choosing to purchase a holiday and run a car, Pauline positioned herself as having the same identity as some, in this case holiday makers and car owners, but a different one from others, for example college students with no income. Pauline was focused on maintaining the lifestyle of an income earner and most of her home literacy practices reflected how careful she was with her money, always keeping a very close check on her spending. She explained she was 'very organised' with her bank statements, kept all her receipts with her card and listened to phone banking 'every day ', so that she knew how much money she had left. When discussing saving for her holiday with her boyfriend, Pauline used her literacy practices to demarcate her own role as the person in charge of their finances. She explained 'he's left it all up to me to organize, so I just take the money off him every week now. I organize us, rather than leaving it to him because it'd get to July and he'd have no money left.' (Barton and Hamilton 
1998). Pauline also enjoyed shopping and fashion, ordering clothes from a mail order catalogue so that she could keep up with current clothing trends but, at the same time, spread the costs, exclaiming 'I like my shoes and my bags!'

\section{Pauline's aspirational identity}

After completing her childcare course, Pauline aimed to go to university to train as a primary school teacher, explaining 'I like more academic things like teaching.', revealing that the childcare course was her route into university:

It is primary teaching I want to do, not nursery nursing really. I don't mind working with the babies but I'd rather do teaching so it's a shame they've not got a course just straight into primary teaching instead of having to do all the nursery nursing bit first, then going to university.

Pauline's identity as a nursery teacher was transitional; she was a childcare student but ultimately aspired to be a primary school teacher.

\section{What became of Pauline?}

Pauline failed to complete the first year of her Childcare course and, as a consequence, was not allowed to progress further. She wrote too much in her assignments and was unable to condense it ahead of the submission deadline. She also got into trouble at her nursery placement by writing college assignments instead of working with the children. Finally, she failed to meet the 
good time keeping criteria on her placement log and, consequently, her supervisor had refused to sign it, resulting in Pauline failing her work placement too.

An exploration of Pauline's former, current and aspirational identities has shown that she appeared to have gained values and acquired literacy practices from her former identities which had the potential to resonate with, and support, her current student identity. Within her student identity, Pauline seemed to be more engaged with the literacy practices associated with her placement than those associated with the classroom, due to the consistency of her sense of who she was at this setting (Ivanic et al. 2009). At the nursery, Pauline was a paid employee for part of the time and on an unpaid placement for the rest of the time. The need to earn money was a motivating factor to Pauline when she carried out the same literacy practices as an unpaid nursery student and as a paid employee. To retain her working identity, Pauline chose to engage with the literacy practices which were common across both her working and student identities, yet she failed both the college and nursery practice components of her course.

The reasons for Pauline's failure on her course were threefold. Firstly, her home literacy practices reveal that the dominant force behind her partial disengagement with her college course (missing sessions, not taking part in all class activities, submitting homework late), resulting in late submission of assignments and failing her work placement due to poor punctuality, was her inability to fully embrace her current student identity. In Pauline's case, her identity was too 'multi-faceted' for her to accommodate. Her identity as an employee and wage earner conflicted and created tension with her student identity (Ivanic et al. 2009, Woodward 2002). Pauline seemed to only partially identify with being a student, not fully accepting what was required of her, failing to hand in her essays on time and, without a wholehearted identity commitment, deep learning could not occur (Gee 2008). 
Secondly, in class, Pauline's preferred literacy practices clashed with those required by her teacher, Linda, contributing to her disengagement (Smyth and Fasoli 2007). Thirdly, and primarily, I suggest that it was Pauline's agency, her choice to retain the lifestyle of a salary earner as opposed to, and at the expense of, adopting the identity of the college student that caused her disengagement with her college course. Pauline chose to spend her time working and was unable to subdue her working identity to become a 'good' student, participating fully in class, being punctual and submitting work on time and to required standards.

\section{Case study two: Katy}

Katy, like Pauline, was also in her 20s, and lived with her partner, three year old son, Daniel, and their new puppy. Katy was close to her family, particularly her mother, who she saw daily. She was in the process of moving house to live on the same street as her sister, 'around the corner' from her mother and 'five minutes away' from her two brothers. Alongside attending college and her work placement each week, Katy was also employed by a local playgroup every Tuesday morning.

Katy's identities

Like Pauline, Katy also had a 'multi-faceted' identity. She was a college student, a mother, a partner and had the ambition to be a teaching assistant in future. I will now present Katy's identities and her literacy practices, across the college and home domains. 


\section{Katy's current identity}

As a college student, Katy did not have a computer at home to type assignments but, once she had moved house, she intended to buy one. Without a home computer, Katy was forced to handwrite her assignments but her teacher was happy to accept them in this format. Katy presented herself as someone who wrote a lot and enjoyed it. As a child, she did not have a computer at home, explaining 'everybody else from primary school had computers, I was always writing. I just do so much of it. I think it's got me liking it' adding 'I love writing, oh I love writing!' At primary school, Katy saw herself as different to 'everybody else' who had computers but her enthusiasm for handwriting was reflected by her passionate, repeated declaration of her 'love' of writing. Although Katy was forced to write, her degree of human agency limited by material constraints (Woodward 2002), she saw it as a pleasure.

Katy's joy in handwriting was evident in the classroom. When asked to take notes from PP, in contrast to Pauline, Katy did not pause, even when her tutor left the classroom. Pauline also noticed Katy's love for hand writing 'Katy, she likes writing loads, she can sit there all day

...' Pauline's use of the pronoun 'she' when referring to Katy, constructed a relation of difference, positioning herself as very different to Katy, who appeared to be physically and cognitively engaged with this classroom literacy practice. Katy also completed hand written tasks far ahead of her peers and had learned 'the right moves'. She was not just 'playing the game' but fully identifying with the classroom literacy practices and enjoying them (Gee 2004). There was a clear correlation between how Katy acted in the classroom and how her teacher expected her to act, revealing a pattern of social assertion that a significant other, Katy's teacher, recognised and expected (Locke Davidson 1996). Presenting herself as a model student, Katy, in contrast to Pauline, conformed with all the literacy practices required by her tutor: taking notes 
when asked, even when unsupervised; making a record of her homework to ensure that she did it and completing all the written activities given to her.

At home, Katy carried out a range of literacy related activities for her young son, her storying centrally focussed on her identity as a mother. She told me about filling out Daniel's enrolment and medical forms for his nursery, reading his child protection form and paying his nursery bill. Katy had also read reminders and explanatory leaflets for Daniel's vaccinations and had completed a dentist registration form. When asked about her hobbies, the extent of Katy's identification with being a mother became clear 'at the minute like, I haven't got time for doing anything ... Daniel, [laughter], Daniel is my hobby I do everything ... everything revolves around Daniel'. Katy's declaratives 'Daniel is my hobby' and 'everything revolves around Daniel $^{`}$ illustrated the amount of time Katy devoted to Daniel and the high priority she allocated to her parenting role.

In addition to the literacy practices that Katy carried out for Daniel, she also carried out a range of literacy practices with him. Every night, Katy read Daniel a bedtime story explaining 'he's absolutely obsessed with books, he loves it, which is good really', adding that Daniel was 'phew ... way ahead!' of children she looked after of a similar age. In her identity as a mother, Katy placed a high value on literacy and literacy education. She was not only keen to help and support Daniel but also to generate a passion within him for reading and writing. Pride in the impact that Katy was having on Daniel's emerging literacy was reflected in her comment that he was 'way ahead' of his peers. She explained ' It's me egging him on all the time ... because I see the children, what level they are at and push him'. As Daniel's mother, Katy was utilising her own knowledge and experience of the literacy development rates of children of a similar age to Daniel gained through her part time job and her college course. 
As well as being a mother, Katy was a partner with the role of looking after the finances which she asserted through her literacy practices, used to distinguish what she did in the household compared to what her partner did (Barton and Hamilton 1998). Katy's frequent use of the personal pronoun 'I' within her discourse reflected the extent of her own input in the reading, paying and filing the household bills into an alphabetical folder 'I tend to fill forms out for him, I tend to read things for him ...' adding 'I seem to do everything like that'. She received little assistance from her partner 'He [her partner] doesn't do ... he's the opposite of me'.

\section{Katy's aspirational identity}

After the course, Katy had considered teacher training but, with a young child, she considered it would be 'a lot of study' adding that 'time wise it's difficult doing this [her current course] now so ...' Instead, she was contemplating working as a classroom teaching assistant.

\section{What became of Katy?}

After completing all of her assignments on time with high grades, Katy progressed to the second year of the course. The reasons for Katy's success were fourfold. Firstly, Katy's literacy practice of handwriting was a common factor across her identities. At college, handwriting assignments created resonance for Katy as this was something she enjoyed doing and her teacher supported this resonance, happy to accept handwritten work. Handwriting was a practice which linked Katy's other identities, as a mother and partner. 
Secondly, in contrast to Pauline, Katy appeared to be fully engaged with her Childcare course. She chose to fully identify and actively engage with her course, just as Pauline chose when to engage disengage. According to Linda, Katy was physically engaged, always in class, arriving on time and taking part in subject related activities. Katy 'stayed 'till 4.30 to get the [college] bus because she'll go down to the library and she'll do her assignments ...' Katy was also psychologically engaged as she met all her coursework deadlines, choosing to work in class even when her tutor was absent. Katy appeared to maximise her spare time for the benefit of her college course, using the library to complete homework. She was emotionally engaged with her course, enthusing how she 'loved' the written components. Katy had 'learned the right moves' and did more than 'play the game' - she enjoyed her college course and fully identified with being a student.

Thirdly, Katy was fully committed to her college course despite all the pressures in her life caused by her identities. Katy had very little negotiable time for herself, with no hobbies or interests other than her son. Like Pauline, Katy did not have an abundance of time for her studies but, unlike Pauline, Katy's multiple identities did not create tension and conflict. Katy perceived her student identity as an important addition to her already multi-faceted identity. To succeed as a student, Katy had undergone 'identity formation' (Smyth and Fasoli 2007), accommodating all her identities, together with their associated expectations and requirement, in order to act within the narrowly defined and institutionalized view of what it meant to be a 'good student'. Finally, Katy appeared to have a clear and realistic aspirational identity to be a classroom assistant, in contrast to Pauline's aspirational identity which was more challenging to turn into reality. Katy appeared to value her course as a means to access future employment 
opportunities. Whereas Pauline placed a higher value on using her time to earn money to retain her non student identity as a money earner, Katy's focus remained solidly on her student identity.

\section{Summary and conclusions}

The study has built on the research carried out by the LfLFE Project (Ivanic 2009, Ivanic et al. 2007, 2009) which found that a person's identity affects the literacy practices they become involved with, the purposes they aim to meet, the meaning they derive from the texts and the values which they attach to these texts and practices. The study has demonstrated that there are specific literacy practices associated with specific identities and that aspects of these are utilized, and engaged with, by students in the college classroom to support their learning. It has also shown that identity is a fundamental part of, and an influencing factor upon, the literacy practice itself.

FE students have more than one student identity; they have multi-faceted identities. The study has shown that the strength of the student identity, and how far a person fully identifies with 'being a student', can be a factor in student success or failure. It also demonstrates that the multi-faceted identities of college students are related to their engagement or disengagement with the literacy practices within the classroom and, consequently, their learning. A summary of the arguments made in this study are threefold:

Firstly, engagement with college based literacy practices may occur if the student fully identifies with being a learner and its associated practices. Katy, despite looking after her family and organizing her household, committed herself fully to her studies. Katy had a genuine 
enjoyment of being a student and an inner desire to do well. Her self-perception was that of someone who could actually learn in the classroom. By contrast, disengagement may also occur by a student not fully identifying with the student identity and its associated literacy practices. Pauline enrolled on her Childcare course but opted to carry out many hours of paid work in order to maintain the lifestyle she had in her working identity to the detriment of time spent on her college studies.

Secondly, the engagement of a student with college based literacy practices may also occur if these practices resonate with those which are present within other aspects of the student's identity (Goodman, Mannion and Brzeski 2007, Mannion 2006, Mannion and Goodman 2006, Mannion et al. 2009, Satchwell 2007, Schwartz 1973). Katy enjoyed handwriting her notes in class and her college assignments as much as she liked to handwrite as a mother and partner. However, disengagement may also occur if there is dissonance between college literacy practices and those of a student's other identities. Pauline enjoyed underlining key points on handouts and taking notes, as she did as an administrator, but disliked copying out notes word for word in class, required by her teacher.

Thirdly, engagement of a student with college classroom literacy practices may take place if there is a resonance between these literacy practices and those of the student's aspirational identity. One reason why Katy identified so strongly with the literacy practices of being a student is that there was congruence between the literacy practices of Katy's current identity as a nursery nurse and those of her aspirational identity as a classroom assistant.

My own empirical findings provide a closer understanding of the implications of this research, both pedagogical and andragogical, for classroom teachers in both the FE and the 
Higher Education (HE) sectors, for curriculum designers in all subject areas, as well as for FE managers, awarding bodies and policy makers. I suggest that the findings may be relevant to other teaching and learning situations in FE and HE and that more research should be carried out in this field. A detailed study on the relationship between a student's literacy practices and aspirational identity would be particularly useful.

Despite the contribution of the findings to our understanding of FE college students' literacy, learning and identities, some caveats are in order. First of all, my study was carried out within the FE sector, only including participants who studied within FE. For future research, it would be worthwhile including other empirical settings, for example secondary schools and Higher Education. Secondly, the study relied on photographs and interviews carried out within the college to gather data surrounding home literacy practices. I suggest that future studies should include interviews within the home domain, subject to the mandatory risk assessments and safeguarding requirements.

\section{References}

Barton, D. 2007. Literacy: An introduction to the ecology of written language (Second Edition) Oxford: Blackwell.

Barton, D. and M. Hamilton. 1998. Local Literacies: Reading and Writing in one community. London: Routledge.

Barton, D and M. Hamilton. 2000. "Literacy Practices." In Situated Literacies: Reading and Writing in Context, edited by Barton, D., M. Hamilton, and R. Ivanic, 7-15. London: Routledge. 
Barton, D., M. Hamilton and R. Ivanic, eds. 2000. Situated Literacies: Reading and Writing in Context. London: Routledge.

Brown, S. 2008. A Critical Discourse Analysis of Literacy Practices and Identity: Latino English Language Learners at Home and in the Primary Classroom. Germany: VDM Verlag Dr. Muller.

Brzesk, A. 2008. Portfolio Building: The relationship with literacies in students' everyday lives, Literacy \& Numeracy Studies. 16 (1): 25-37.

http://epress.lib.uts.edu.au/journals/index.php/lnj/article/view/1946/2094

Chappell, C., C. Rhodes, N. Soloman, M. Tennant and L. Yates, L. 2003. Reconstructing the Lifelong Learner: Pedagogy and Identity in Individual, Organisational and Social Change. London: Routledge.

Dilman, I. 1991. Sartre and Our Identity as Individuals, Royal Institute of Philosophy Supplement, 29, 245-264.

Duckworth, V. and Brzeski, A. 2015. Challenges to Neoliberalism: Literacy, learning and identity, Research in Post-Compulsory Education and Training, 20 (1): 1-16.

http://www.tandfonline.com/doi/full/10.1080/13596748.2015.993861\#

Foucault, M. 1978. The History of Sexuality. Volume 1. New York: Vintage.

Fowler, E. and J. Mace. 2005. Outside the Classroom: Researching Literacy with Adult Learners. NIACE: Leicester.

Gee, J. P. 2015. Social Linguistics and Literacies - Ideology in Discourse. $5^{\text {th }}$ ed. London: Routledge. 
Gee, J. P. 2008. What video games have to teach us about learning and literacy. New York: Palgrave Macmillan.

Gee, J. P. 2004. Situated Language and Learning: A critique of traditional schooling. New York: Routledge.

Goodman, R., G. Mannion, and A. Brzeski. 2007. "Reading, Writing and Resonance: An Experiential Workshop for Practitioners." Research and Practice in Adult Literacy Journal: Special issue for RAPAL Conference 2006 (61): 10-14.

Hamilton, M. 2012. Literacy and the Politics of Representation. London: Routledge.

Hodge, R. and K. Jones. 2000. "Photography in collaborative research on multilingual literacy practices." In Multilingual Literacies: Reading and writing different worlds, edited by MartinJones, M. and K. Jones, 299-318, Amsterdam/Philadelphia,:John Benjamins Publishing Company.

Hull, G. and K. Schultz. 2002. "Connecting Schools with Out-of-School Worlds: Insights from Recent Research on Literacy in Non-School Settings." In School's Out!:Bridging Out-of-School Literacies with Classroom Practice, edited by Hull, G. and K. Schultz, 32-57. New York: Teachers College Press.

Ivanic, R. 2009. "Bringing literacy studies into research on learning across the curriculum." In The Future of Literacy Studies, edited by Baynham, M. and M. Prinsloo, 100-122. Basingstoke: Palgrave MacMillan. 
Ivanic, R., R. Edwards, D. Barton, M. Martin-Jones, Z. Fowler, B. Hughes, G. Mannion, K. Miller, C. Satchwell, and J. Smith. 2009. Improving Learning in College: Rethinking literacies across the curriculum. London: Routledge.

Ivanic, R., R. Edwards, C. Satchwell, and J. Smith. 2007. "Possibilities for pedagogy in Further Education: Harnessing the abundance of literacy." British Educational Research Journal, 33 (5): 703-721.

Ivanič, R. and C. Satchwell. 2007. "Boundary crossing: Networking and transforming the literacies in research processes and college courses." International Journal of Applied Linguistics, Special Issue on New Directions in Academic Literacies Research, 4 (1): 101-124.

Kershen, A. J. 1998. A Question of Identity. Aldershot: Ashgate Publishing Limited.

Lewis, C., P. Enciso, and E. B. Moje. 2007. Reframing Sociocultural Research on Literacy: Identity, Agency and Power. London: Lawrence Erlbaum Associates.

Locke Davidson, A. 1996. Making and Molding Identity in Schools. New York: State University of New York Press.

Luttrell, W. and C. Parker. 2001. "High school students' literacy practices and identities, and the figured world of school.” Journal of Research in Reading, 24 (3): 235-247.

Mannion, G. (2006) Viewpoint: Striking a Chord, Broadcast, 71, 40-41.

Mannion, G. and R. Goodman. 2006. "Striking a chord: making coursework and curricula more resonant with students' everyday lives.” Literacies for Learning in Further Education Project newsletter (4), 4. 
Mannion, G., K. Miller, I. Gibb, and R. Goodman, R. 2009. "Reading, writing, resonating: striking chords across the contexts of students' everyday and college lives." Pedagogy, Culture \& Society, 17 (3): 323-329.

Miller, D. 1997. “Consumption and its consequences.” In Consumption and everyday life, edited by Mackay, H., 13-64. London: Sage Publications Ltd.

Pahl, K. and J. Rowsell. 2005. Literacy and Education: Understanding the New Literacy Studies in the Classroom. London: Sage Publications Ltd.

Papen, U. 2005. Adult literacy as social practices - more than skills. London: Routledge.

Paris, D. and N. T. Winn. 2014. Humanising Research: Decolonizing Qualitative Inquiry with Youth and Communities. London: Sage Publications Ltd.

Satchwell, C. 2007. "Creating third spaces: Helping Further Education students with courserelated reading and writing." The Teacher Trainer 21 (2): 11-14.

Schwartz, T. 1973. The Responsive Chord. New York: Anchor.

Smith, J. 2005. "Mobilising everyday literacy practices within the Curricula.” Journal of Vocational Education and Training 57 (3): 319-334.

Smyth, J, and L. Fasoli. 2007. "Climbing over the rocks in the road to student engagement and learning in a challenging high school in Australia." Educational Research 49 (3): 273-295.

Street, B. V. 1984. Literacy in Theory and Practice. Cambridge: Cambridge University Press.

Woodward, K. 2002. Understanding Identity. London: Arnold. 
Woodward, K. 2004. Questioning Identity: Gender, Class, Ethnicity. London: Routledge.

Wortham, S. 2006. Learning Identity: The Joint Emergence of Social Identification and Academic Learning. Cambridge: Cambridge University Press. 